\title{
A child with intravenous immunoglobulin-resistant Kawasaki disease who responded to intravenous methyl prednisolone
}

\author{
*Imalke Kankananarachchi ${ }^{1}$, Pujitha Wickramasinghe ${ }^{2}$, Meranthi Fernando ${ }^{3}$, Kaushalya Pussagoda ${ }^{4}$, \\ Ruwangi Dissanayake ${ }^{2}$, Ruwan Morawakkorala ${ }^{4}$, Harendra de Silva ${ }^{2}$
}

Sri Lanka Journal of Child Health, 2019; 48(3): 270-272

DOI: http://dx.doi.org/10.4038/sljch.v48i3.8767

(Key words: Kawasaki disease, immunoglobulin resistance, steroids, Sri Lanka)

\section{Introduction}

Kawasaki disease (KD) is an acute febrile illness in children with lethal outcome due to associated coronary artery aneurysm ${ }^{1}$. Intravenous immunoglobulin (IVIG) is the standard treatment of KD. IVIG resistance occurs in approximately $15 \%$ of patients with $\mathrm{KD}$ and carries a poor prognosis $^{2}$. We report a child with IVIG resistant KD who responded to intravenous (IV) methylprednisolone.

\section{Case Report}

A 5 year old boy presented with 6 days history of fever, irritability, and arthralgia. Physical examination revealed a maculopapular rash, conjunctival injection, strawberry tongue and peripheral oedema. There was no cervical lymphadenopathy or BCG induration. Rest of his examination was unremarkable. Initial laboratory results on admission revealed normal blood counts, elevated inflammatory markers, hypoalbuminaemia and sterile pyuria. Echocardiography done on day 6 , showed no coronary artery abnormalities or myocarditis.

The diagnosis of KD was made based clinically and he was given IVIG $2 \mathrm{~g} / \mathrm{kg}$ with aspirin $100 \mathrm{mg} / \mathrm{kg} /$ day. There was no clinical improvement with the treatment. The repeat investigations on the $9^{\text {th }}$ day of the illness revealed neutrophil leucocytosis, anaemia, elevated C-reactive protein (CRP) and erythrocyte sedimentation rate (ESR) (Table 1).

Table 1: Summary of laboratory investigations

\begin{tabular}{|l|c|c|c|c|}
\hline \multicolumn{1}{|c|}{ Investigation/ Day } & $\mathbf{4}$ & $\mathbf{9}$ & $\mathbf{3 2}$ & $\mathbf{4 0}$ \\
\hline White blood cell count (/cu mm) & 10,300 & 23,800 & 20,800 & 10,800 \\
\hline Neutrophils (\%) & 54.2 & 73 & 68.5 & 63 \\
\hline Haemoglobin (g/dL) & 11.8 & 8.0 & 6.0 & 8.1 \\
\hline Platelet count (/cu mm) & $288 \times 10^{3}$ & $402 \times 10^{3}$ & $610 \times 10^{3}$ & $640 \times 10^{3}$ \\
\hline C-reactive protein (mg/dL) & 96 & 110 & 145 & 5 \\
\hline Erythrocyte sedimentation rate (mm 1 ${ }^{\text {st }}$ hour) & 45 & 122 & 144 & 56 \\
\hline
\end{tabular}

${ }^{1}$ Faculty of Medicine, University of Ruhuna, Sri Lanka, ${ }^{2}$ Faculty of Medicine, University of Colombo, Sri Lanka, ${ }^{3}$ Faculty of Medicine, University of Kelaniya, Sri Lanka, ${ }^{4}$ Lady Ridgeway Hospital for Children, Colombo, Sri Lanka,

*Correspondence: imalke462@gmail.com

iD orcid.org/ 0000-0002-9351-2966

(Received on 19 November 2017: Accepted after revision on 22 December 2017)

The authors declare that there are no conflicts of interest

Personal funding was used for the project.

Open Access Article published under the Creative

Commons Attribution CC-BY cc)
On the $14^{\text {th }}$ day of the illness, repeat echocardiography showed dilatation of coronary arteries for which a second dose of IVIG was given. (Table 2)

Despite the two doses of IVIG, there was no clinical improvement. Investigations on day 32 showed worsening of the haematological and inflammatory markers. (Table 1)

Third echocardiography done on $35^{\text {th }}$ day of illness revealed worsening of coronary artery dilatation and appearance of another aneurysm (Figure 1). 
Table 2: Echocardiographic findings

\begin{tabular}{|c|c|c|c|c|c|}
\hline Onset (day) & 6 & 14 & 35 & 40 & 60 \\
\hline LMCA (mm) & 2.0 & 2.7 & 2.6 & 2.5 & 2 \\
\hline $\begin{array}{l}\text { Proximal } \\
\text { LADA }(\mathrm{mm})\end{array}$ & 1.6 & 2.1 & 4.0 & 4.6 & 3.1 \\
\hline RCA (mm) & 1.8 & 2.5 & 4.7 & 4.6 & 4.0 \\
\hline Aneurysms & No & $\begin{array}{lr}\text { At } & \text { bifurcation } \\
\text { of } & \text { LMCA } \\
2.7 \mathrm{~mm} & \end{array}$ & $\begin{array}{l}\text { 1.At bifurcation of } \\
\text { LMCA } 6 \mathrm{~mm} \\
\text { 2.LADA aneurysm } \\
\text { of } 6 \mathrm{~mm}\end{array}$ & $\begin{array}{l}\text { 1.At bifurcation of } \\
\text { LMCA } 5.4 \mathrm{~mm} \\
\text { 2.LADA aneurysm } \\
\text { of } 6 \mathrm{~mm}\end{array}$ & $\begin{array}{l}\text { 1.At bifurcation of } \\
\text { LMCA } 4.2 \mathrm{~mm} \\
\text { 2.LADA aneurysm } \\
\text { of } 5.8 \mathrm{~mm}\end{array}$ \\
\hline
\end{tabular}

LMCA - Left main coronary artery, RCA-Right coronary artery, LADA-Left anterior descending artery
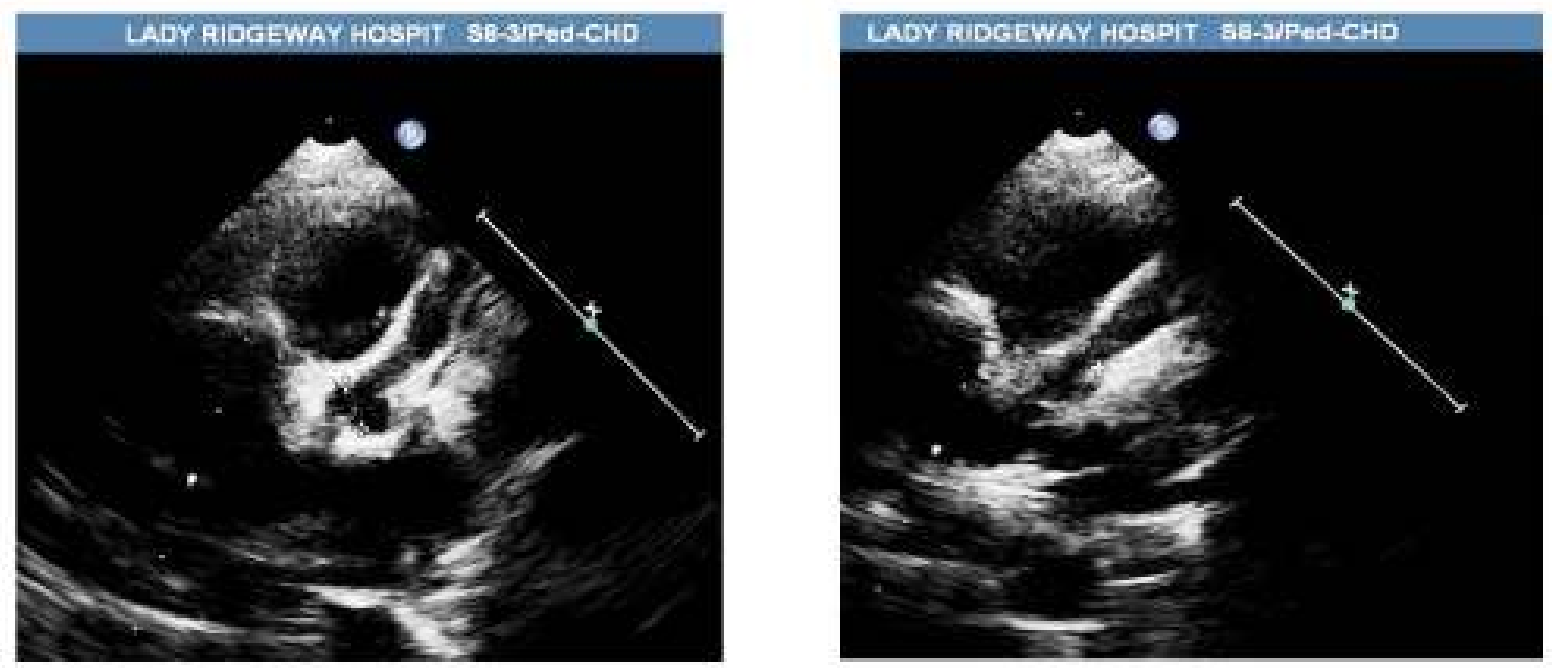

Figure 1: Dilated coronary arteries and coronary artery aneurysm at LMCA \& LADA on day 35

He was started on IV methylprednisolone $30 \mathrm{mg} / \mathrm{kg}$, continued for three days, followed by oral prednisolone for 2 weeks.

\section{Discussion}

$\mathrm{KD}$, which was previously called mucocutaneous lymph node syndrome, is more common in Asian children ${ }^{1}$. The diagnosis of KD is based entirely on clinical features and basic laboratory investigations. In order to prevent coronary artery involvement, it is essential to establish the diagnosis early in the disease and to commence treatment ${ }^{2}$.

IVIG has been the main treatment modality in KD. IVIG therapy given at $2 \mathrm{~g} / \mathrm{kg}$ during the first 10 days of the disease has reduced the incidence of coronary artery aneurysm from $25 \%$ to $5 \%{ }^{2}$.

IVIG resistant $\mathrm{KD}$ is defined as a persistent or recrudescent fever 36 hours after completion of the initial IVIG infusion ${ }^{3}$. Since patients with IVIG resistance $\mathrm{KD}$ are at increased risk of developing coronary artery aneurysms it is recommended to give another dose of $\mathrm{IVIG}^{1}$.

There is no consensus on second line therapy for those who failed to respond to two doses of IVIG. Before the availability of IVIG, prednisolone has been used as a first line therapy for $\mathrm{KD}^{2}$. Few case series have showed the effectiveness of corticosteroids in halting the progression of coronary artery abnormalities in children with IVIG resistant $\mathrm{KD}^{3-5}$. A small comparative study showed that intravenous methylprednisolone $30 \mathrm{mg} / \mathrm{kg}$ for 3 days was superior in terms of suppressing the fever but the incidence of coronary artery aneurysm was similar in both groups ${ }^{6}$. In this child, clinical improvement was noted only after starting IV methylprednisolone therapy and there was no progression of the coronary artery dilatation and aneurysm formation after that. In addition to steroids and IVIG, plasmapheresis, cyclophosphamide, ulinastatin and abciximab are the available treatment options for IVIG resistant $\mathrm{KD}^{10}$.

\section{References}

1. Son MB, Newburger JW. Kawasaki Disease. In: Kleigman RM, Stanton BMD, St. Geme J, Schor NF, Behrman RE, editors. Nelson Textbook of Paediatrics $20^{\text {th }}$ edition, Vol-1. Elsevier: 2015; p.1209 -14 .

2. Diagnosis, treatment, and long-term management of Kawasaki disease: a 
statement for health professionals from the Committee on Rheumatic Fever, Endocarditis, and Kawasaki Disease, Council on Cardiovascular Disease in the Young, American Heart Association. Pediatrics 2004; 114(6): 1708-33. https://doi.org/10.1542/peds.2004-2182 PMid: 15574639

3. Lee JH, Hung HY, Huang FY. Kawasaki disease with Reye syndrome: report of one case. Zhonghua Min Guo Xiao Er Ke Yi Xue Hui Za Zhi. 1992; 33(1): 67-71.

PMid: 1626454

4. Wallace CA, French JW, Kahn SJ, Sherry DD. Initial intravenous gamma globulin treatment failure in Kawasaki disease. Pediatrics. 2000; 105:E78.

PMid: 10835091

5. Wright DA, Newburger JW, Baker A, Sundel RP. Treatment of immune globulin-resistant Kawasaki disease with pulsed doses of corticosteroids. Journal of Pediatrics 1996; 128: 146-9.

https://doi.org/10.1016/S00223476(96)70 447-X
6. Dale RC, Saleem MA, Daw S, Dillon MJ. Treatment of severe complicated Kawasaki disease with oral prednisolone and aspirin. Journal

of

Pediatrics 2000; 137:723-6.

PMid: 11060542

7. Zaitsu M, Hamasaki Y, Tashiro K, Matsuo M, Ichimaru T, Fujita I, Tasaki H, Miyazaki S. Ulinastatin, an elastase inhibitor, inhibits the increased mRNA expression of prostaglandin $\mathrm{H} 2$ synthasetype 2 in Kawasaki disease. Journal of Infectious Diseases 2000; 181: 1101-9. PMid: 10720537 